\title{
Enhancement of glucagon secretion in mouse and human pancreatic alpha cells by protein kinase $C$ (PKC) involves intracellular trafficking of $\mathrm{PKC} \alpha$ and $\mathrm{PKC} \delta$
}

\author{
Y. Z. De Marinis • E. Zhang • S. Amisten • J. Taneera • \\ E. Renström $\cdot$ P. Rorsman $\cdot$ L. Eliasson
}

Received: 28 August 2009/Accepted: 19 November 2009/Published online: 18 December 2009

(C) Springer-Verlag 2009

\begin{abstract}
Aims/hypothesis Protein kinase C (PKC) regulates exocytosis in various secretory cells. Here we studied intracellular translocation of the $\mathrm{PKC}$ isoenzymes $\mathrm{PKC} \alpha$ and $\mathrm{PKC} \delta$, and investigated how activation of PKC influences glucagon secretion in mouse and human pancreatic alpha cells.

Methods Glucagon release from intact islets was measured in static incubations, and the amounts released were determined by RIA. Exocytosis was monitored as increases in membrane capacitance using the patch-clamp technique. The expression of genes encoding PKC isoforms was analysed by real-time PCR. Intracellular PKC distribution was assessed by confocal microscopy.

Results The PKC activator phorbol 12-myristate 13-acetate (PMA) stimulated glucagon secretion from mouse and human islets about fivefold $(p<0.01)$. This stimulation was abolished by the PKC inhibitor bisindolylmaleimide (BIM). Whereas PMA potentiated exocytosis more than threefold $(p<0.001)$, BIM inhibited alpha cell exocytosis by $60 \%(p<0.05)$. In mouse islets, the PKC isoenzymes, $\mathrm{PKC} \alpha$ and $\mathrm{PKC} \beta 1$, were highly abundant, while in human islets $\mathrm{PKC} \eta, \mathrm{PKC} \varepsilon$ and $\mathrm{PKC} \zeta$ were the dominant variants. PMA stimulation of human alpha cells correlated with the
\end{abstract}

Y. Z. De Marinis $(\triangle) \cdot$ E. Zhang $\cdot$ J. Taneera $\cdot$ E. Renström

L. Eliasson

Lund University Diabetes Centre, Department of Clinical

Sciences, Clinical Research Centre, Lund University,

CRC 91-11, UMAS entrance 72,

SE-20502 Malmö, Sweden

e-mail: Yang.De_Marinis@med.lu.se

S. Amisten · P. Rorsman

Oxford Centre for Diabetes, Endocrinology \& Metabolism,

University of Oxford, Churchill Hospital,

Oxford, UK translocation of $\mathrm{PKC} \alpha$ and $\mathrm{PKC} \delta$ from the cytosol to the cell periphery. In the mouse alpha cells, PKC $\delta$ was similarly affected by PMA, whereas PKC $\alpha$ was already present at the cell membrane in the absence of PMA. This association of $\mathrm{PKC} \alpha$ in alpha cells was principally dependent on $\mathrm{Ca}^{2+}$ influx through the L-type $\mathrm{Ca}^{2+}$ channel. Conclusions/interpretation PKC activation augments glucagon secretion in mouse and human alpha cells. This effect involves translocation of $\mathrm{PKC} \alpha$ and $\mathrm{PKC} \delta$ to the plasma membrane, culminating in increased $\mathrm{Ca}^{2+}$-dependent exocytosis. In addition, we demonstrated that $\mathrm{PKC} \alpha$ translocation and exocytosis exhibit differential $\mathrm{Ca}^{2+}$ channel dependence.

Keywords BIM $\cdot \mathrm{Ca}^{2+} \cdot$ Glucagon $\cdot$ Exocytosis $\cdot$ Pancreatic alpha cell $\cdot \mathrm{PKC} \cdot \mathrm{PKC} \alpha \cdot \mathrm{PKC} \delta \cdot \mathrm{PMA} \cdot$ Translocation

$\begin{array}{ll}\text { Abbreviations } \\ \text { BIM } & \text { Bisindolylmaleimide } \\ \text { Munc-18 } & \text { Mammalian homologue of Unc-18 } \\ \text { PKC } & \text { Protein kinase C } \\ \text { PMA } & \text { Phorbol 12-myristate 13-acetate } \\ \text { RRP } & \text { Readily releasable pool }\end{array}$

\section{Introduction}

Glucagon is produced by the pancreatic alpha cells and released in response to decreased blood glucose. It is the most important hyperglycaemic hormone in animals and man [1, 2]. Glucagon increases plasma glucose by promoting hepatic glycogenolysis. In type 2 diabetes, the normal balance between glucagon and insulin is disturbed [3]. Collectively, these defects culminate in increased 
hepatic glucose production [4]. Because of its important role in hyperglycaemia in type 2 diabetes, glucagon has become a very attractive target for diabetes research.

Glucagon secretion is regulated through paracrine, metabolic and hormonal/neuronal mechanisms [5]. The latter includes adrenaline (epinephrine) [6, 7], glucagonlike peptide 1 [8], somatostatin [9] and glucagon itself [10]. Like the neighbouring beta and delta cells [11], alpha cells are electrically excitable and fire action potentials at low glucose concentrations or when glucagon secretion is stimulated by amino acids like arginine [12]. These action potentials result from the opening of voltage-gated $\mathrm{K}^{+}, \mathrm{Na}^{+}$ and $\mathrm{Ca}^{2+}$ channels [13]. We have previously demonstrated that glucagon secretion can be regulated by a $\mathrm{K}_{\text {ATP }}$ channeldependent mechanism in rodent and human alpha cells [14]. Electrical activity is possible in a narrow window of low $\mathrm{K}_{\text {АTP }}$ channel activity, resulting in partial depolarisation, which triggers opening of voltage-gated $\mathrm{Na}^{+}$and $\mathrm{Ca}^{2+}$ channels. Increasing glucose levels have been postulated to mediate the closure of remaining active $\mathrm{K}_{\mathrm{ATP}}$ channels, thereby leading to stronger membrane depolarisation. This in turn causes voltage-dependent inactivation of the membrane conductance involved in action potential firing, culminating in inhibition of glucagon secretion and alpha cell exocytosis. In rodent alpha cells, exocytosis is $\mathrm{Ca}^{2+}$-dependent [13] and basal glucagon secretion principally depends on influx through N-type $\mathrm{Ca}^{2+}$ channels. In addition, alpha cells are equipped with L-type $\mathrm{Ca}^{2+}$ channels, which are important for glucagon secretion occurring under conditions associated with elevation of intracellular cyclic AMP (like in the presence of adrenaline) [6].

Glucagon secretion is also modulated by protein kinase $\mathrm{C}$ (PKC) $[15,16]$. Genetic screening has unveiled ten distinct PKC isotype genes [17]. The PKC superfamily has been subdivided on the basis of properties: conventional/ classical PKCs ( $\alpha, \beta I, \beta I I$ and $\gamma)$, novel PKCs $(\eta, \varepsilon, \delta$ and $\theta$ ) and atypical PKCs $(\mathrm{l} / \lambda$ and $\zeta$ ). Activation of PKC by exogenous diacylglycerol [18, 19] and phorbol esters augments insulin [20] and glucagon secretion in rat [15]. Conversely, pharmacological inhibitors of PKC suppress glucose-induced insulin secretion [21, 22].

Several PKC isoenzymes have been shown to be implicated in control of exocytosis [23-26], including $\mathrm{PKC} \alpha$ [27] and PKC $\delta$ [28], but the effect of PKC on exocytosis in pancreatic alpha cells remains to be established. In rat beta cells, the activation of several PKC isoforms leads to their translocation from the cytosol to the cell membrane [29]. Conventional PKCs are activated by binding to $\mathrm{Ca}^{2+}$ and diacylglycerol, whereas activation of novel PKCs is only sensitive to diacylglycerol [17]. This may explain why $\mathrm{PKC} \alpha$, but not $\mathrm{PKC} \delta$ becomes translocated to the plasma membrane in beta cells in response to the glucose-induced elevation of $\left[\mathrm{Ca}^{2+}\right]_{\mathrm{i}}[27,29]$. Once at the plasma membrane, PKC probably acts by phosphorylating downstream target proteins. One potential PKC substrate is mammalian homologue of Unc-18 (Munc-18). In many cell types, Munc-18 is crucial for the docking and priming of secretory granules, as well as for actual fusion with the plasma membrane [30]. It has been demonstrated that Munc-18 is phosphorylated by PKC in response to phorbol ester treatment [31, 32].

Here we studied PKC-dependent exocytosis and glucagon secretion in mouse and human alpha cells. We also investigated islet level expression of genes encoding PKC isoenzymes as well as the redistribution of the two isoenzymes, $\mathrm{PKC} \alpha$ and $\mathrm{PKC} \delta$, in response to phorbol 12-myristate 13-acetate (PMA) and $\mathrm{Ca}^{2+}$ influx.

\section{Methods}

Tissues and cell culture Islets from NMRI mice were isolated by collagenase digestion. All experimental procedures performed on mice were approved by the Lund-Malmö Ethics Committee. Islets were incubated in $\mathrm{Ca}^{2+}$-free buffer to obtain a suspension of individual cells. Two days prior to experiments, these cells were plated on plastic Petri dishes (for patch-clamp recording) or glass cover slips (for confocal microscopy) and maintained in tissue culture medium for $6 \mathrm{~h}$. The culture medium consisted of RPMI 1640 supplemented with $10 \%$ (vol./vol.) fetal calf serum, $100 \mathrm{IU} / \mathrm{ml}$ penicillin and $10 \mu \mathrm{g} / \mathrm{ml}$ streptomycin. Human islets were from non-diabetic individuals (BMI 17.6$29.0 \mathrm{~kg} / \mathrm{m}^{2}$, aged $26-73$ years) and provided by the Nordic network for clinical islets transplantation (O. Korsgren, Uppsala University, Sweden). The human islets were cultured at $37^{\circ} \mathrm{C}\left(5 \% \mathrm{CO}_{2}\right)$ for 1 to 9 days prior to the experiments in CMRL 1066 (ICN Biomedicals, Costa Mesa, CA, USA) supplemented with $10 \mathrm{mmol} / \mathrm{l}$ HEPES, $2 \mathrm{mmol} / 1 \mathrm{~L}$-glutamine, $50 \mu \mathrm{g} / \mathrm{ml}$ gentamicin, $0.25 \mu \mathrm{g} / \mathrm{ml}$ fungizone (Gibco, BRL, Gaithersburg, MD, USA), $20 \mu \mathrm{g} / \mathrm{ml}$ ciprofloxacin (Bayer Healthcare, Leverkusen, Germany) and $10 \mathrm{mmol} / \mathrm{l}$ nicotinamide. All procedures were approved by the ethical committees at Uppsala and Lund Universities.

In vitro pancreatic islet glucagon release Freshly isolated islets were pre-incubated for $30 \mathrm{~min}$ at $37^{\circ} \mathrm{C}$ in a $\mathrm{KRB}$ buffer (pH 7.4) consisting of (mmol/l) $120 \mathrm{NaCl}, 25$ $\mathrm{NaHCO}_{3}, 4.7 \mathrm{KCl}, 1.2 \mathrm{MgSO}_{4}, 2.5 \mathrm{CaCl}_{2}, 1.2 \mathrm{KH}_{2} \mathrm{PO}_{4}$, 1 glucose, 10 HEPES at $\mathrm{pH} 7.4$ and $1 \mathrm{mg} / \mathrm{ml}$ BSA. The medium was gassed with $95 \% \mathrm{O}_{2}$ and $5 \% \mathrm{CO}_{2}$ to obtain constant $\mathrm{pH}$ and oxygenation. Groups of twelve islets were incubated for $60 \mathrm{~min}$ at $37^{\circ} \mathrm{C}$ in $1 \mathrm{ml} \mathrm{KRB}$ buffer supplemented as indicated. PMA and bisindolylmaleimide (BIM) were purchased from Calbiochem (San Diego, CA, 
USA). Immediately after incubation, an aliquot of the medium was removed to determine glucagon content as previously described [14].

Capacitance measurement Experiments were carried out on mouse alpha cells as detailed elsewhere [10]. Wholecell currents and exocytosis were recorded using an EPC-9 patch-clamp amplifier and Pulse software (version 8.50) (both Heka Electronics, Lambrecht, Germany). Mouse alpha cells were identified by their small size and $\mathrm{Na}^{+}$current inactivation properties [13, 14]. The extracellular medium contained (mmol/l) $118 \mathrm{NaCl}, 20$ tetraethylammonium chloride, $5.6 \mathrm{KCl}, 2.6 \mathrm{CaCl}_{2}, 1.2 \mathrm{MgCl}_{2}, 5$ HEPES (pH 7.4 with $\mathrm{NaOH}$ ) and 5 glucose. The electrophysiological measurements were conducted using the perforated patch technique and pipette solution containing (mmol/l) $76 \mathrm{Cs}_{2} \mathrm{SO}_{4}, 10 \mathrm{NaCl}, 10 \mathrm{KCl}, 1 \mathrm{MgCl}_{2}$ and 5 HEPES ( $\mathrm{pH} 7.35$ with $\mathrm{CsOH}$ ), and $60 \mu \mathrm{g} / \mathrm{ml}$ amphotericin B. Exocytosis was monitored as changes in membrane capacitance using the software-based lock-in function of the Pulse software. Experiments were conducted at 32 to $34^{\circ} \mathrm{C}$.

Relative quantitative real-time $P C R$ Human and mouse pancreatic islets were dissolved in TRIzol (Invitrogen, Carlsbad, CA, USA) and stored at $-80^{\circ} \mathrm{C}$. Total islet RNA was extracted according to a modified TRIzol protocol and reverse-transcribed into cDNA using TaqMan Reverse transcription (Applied Biosystems, Foster City, CA, USA) as described elsewhere [33]. Relative quantitative real-time PCR of human and mouse PKC genes was performed using a kit and primer assays (QuantiFast SYBR Green PCR and QuantiTect; Qiagen, Venlo, the Netherlands) according to the manufacturer's instructions. The expression of genes encoding pancreatic islet PKC was calculated relative to the housekeeping gene $G A P D H$ using the $\Delta \Delta \mathrm{C}_{\mathrm{t}}$ method [34].

Immunohistochemistry Mouse and human islets were dissociated into single cells, plated on glass cover slips and cultured overnight. The culture media were replaced by the same KRB buffer as in the secretion assay during $30 \mathrm{~min}$ of pre-incubation. The cells were then incubated for $1 \mathrm{~h}$ in KRB buffer ( $1 \mathrm{mmol} / \mathrm{l}$ glucose) supplemented with either $1 \mu \mathrm{mol} / 1$ PMA, $400 \mu \mathrm{mol} / 1$ diazoxide or $2 \mu \mathrm{mol} / 1$ isradipine (all from Sigma-Aldrich, Stockholm, Sweden). After incubation, the cells were fixed with $4 \%$ (wt/vol.) paraformaldehyde in $\mathrm{Ca}^{2+}$-free PBS for $1 \mathrm{~h}$ and permeabilised with 5\% (vol./vol.) Triton X-100 overnight. Unspecific binding was blocked with 5\% (vol./vol.) donkey serum (Jackson Immunoresearch Laboratories, Avondale, PA, USA) before incubating with different primary antibodies overnight. The primary antibodies were rabbit anti-PKC $\alpha$ (1:250; Abcam, Cambridge, UK), rabbit anti-PKC反 (1:50; Santa Cruz Biotechnology, Santa Cruz, CA, US), rabbit anti-PKCE (1:250; Abcam, Cambridge, MA, USA) and guinea pig anti-glucagon (1:500; Jackson ImmunoResearch Laboratories). After washing with PBS, the cells were exposed for $2 \mathrm{~h}$ to the following secondary antibodies: DyLight 488 AffiniPure Donkey Anti-rabbit $\operatorname{IgG}(1: 100)$ and anti-guinea pig Cy 5 (1:50; both from Jackson ImmunoResearch Laboratories). The labelled cells were viewed using a confocal microscope (LSM510; Zeiss, Jena, Germany) using the $488 \mathrm{~nm}$ (Сy2) and $633 \mathrm{~nm}$ (Cy 5) lasers for excitation. Unspecific binding of the secondary antibodies was excluded by control experiments performed in the absence of the primary antibodies. The localisation of PKC $\alpha$ and $\mathrm{PKC} \delta$ was quantified by the ratio between the mean fluorescent intensity in an area within $0.5 \mu \mathrm{m}$ from the plasma membrane $\left(I_{1}\right)$ and the cytosolic region $\left(I_{2}\right)$, where $I_{1}=$ $(s 1-s 2) /(a 1-a 2)$ and $I_{2}=(s 2-s 3) /(a 2-a 3)$. Here $s 1$ is the total fluorescence intensity in the cell, $s 2$ is fluorescence in the cytosol and nuclear area, and $s 3$ is the fluorescence in the nuclear area; $a 1$ is the total area of the cell, $a 2$ is the area of cytosol and nuclear section, and $a 3$ is the area of nucleus.

Data analysis The increase in cell membrane capacitance was measured once a steady-state level had been attained. All data are quoted as mean values \pm SEM of the indicated number of experiments $(n)$. Statistical significances were evaluated using Student's $t$ test or two-way ANOVA.

\section{Results}

The effect of PKC-activation and inhibition on glucagon release We measured glucagon secretion from intact mouse islets (Fig. 1a) at 1 or $8.3 \mathrm{mmol} / 1$ glucose with or without PMA (1 $\mu \mathrm{mol} / 1)$, an artificial analogue of diacylglycerol and/or the PKC-antagonist, BIM $(2.4 \mu \mathrm{mol} / 1)$. In agreement with previous studies [14, 35], islets incubated at $8.3 \mathrm{mmol} / 1$ glucose secreted less glucagon than those exposed to $1 \mathrm{mmol} / 1$ glucose $(p<0.01 ; n=6)$. Application of PMA to islets exposed to $1 \mathrm{mmol} / 1$ glucose enhanced glucagon secretion about fivefold $(p<0.01 ; n=6)$. PMA also stimulated glucagon secretion in the presence of $8.3 \mathrm{mmol} / \mathrm{l}$ glucose, albeit to a lesser extent than at $1 \mathrm{mmol} / 1$ glucose. The stimulatory action of PMA was abolished in the presence of BIM, regardless of whether the islets were incubated at 1 or $8.3 \mathrm{mmol} / 1$ glucose. BIM alone reduced glucagon secretion from mouse islets elicited by low glucose $(1 \mathrm{mmol} / \mathrm{l})$ by about $60 \%(p<$ $0.05, n=6)$. Similar results were obtained in human islets (Fig. 1b) with the exception that BIM alone did not reduce 
glucagon secretion at $1 \mathrm{mmol} / 1$ glucose. Collectively, these data implicate PKC in the modulation of glucagon secretion from mouse and human alpha cells.

Treatment with PMA stimulates pancreatic alpha cell exocytosis High-resolution capacitance perforated patch measurements were applied to single mouse alpha cells to

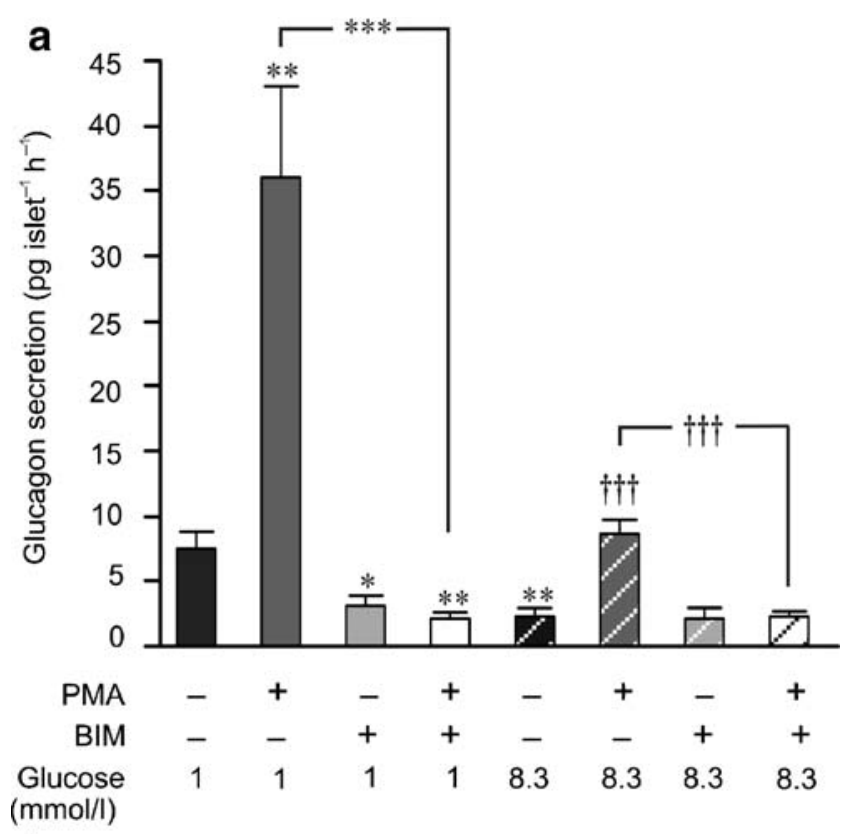

b

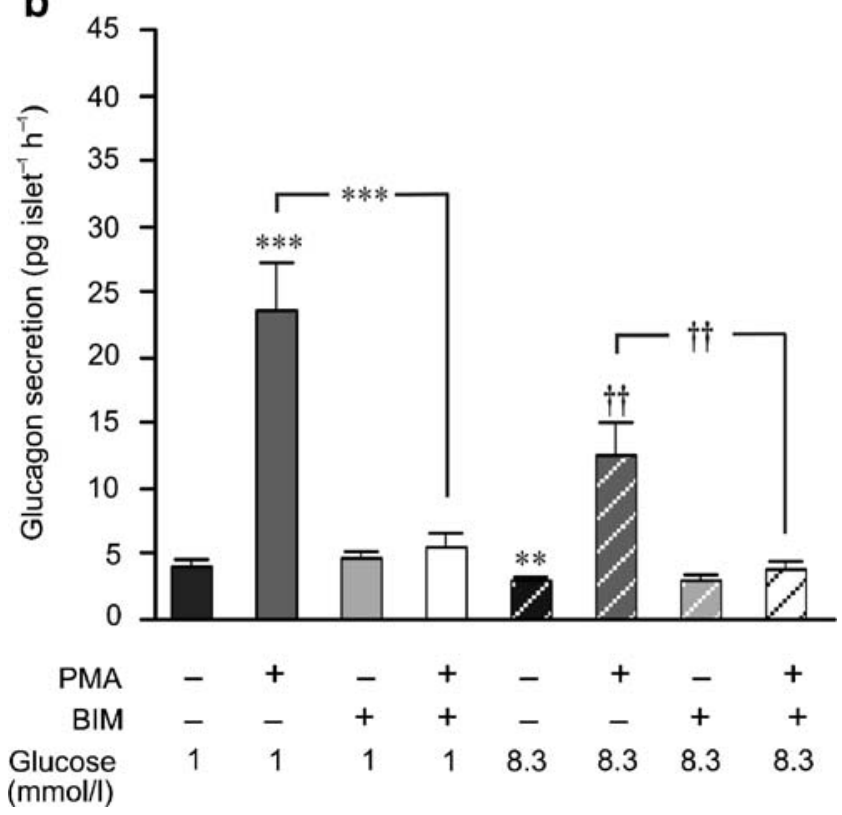

Fig. 1 PKC-dependent glucagon secretion. (a) Glucagon release from mouse islets and (b) human islets was measured at 1 and $8.3 \mathrm{mmol} / \mathrm{l}$ glucose in the presence and absence of PMA $(1 \mu \mathrm{mol} / \mathrm{l})$ and/or BIM $(2.4 \mu \mathrm{mol} / \mathrm{l})$ as indicated. Data are the mean \pm SEM of six experiments with mouse islets and 18 to 25 experiments with human islets (from six donors). ${ }^{*} p<0.05, * * p<0.01, * * * p<0.001$ vs $1 \mathrm{mmol} / 1$ glucose or as indicated; ${ }^{\dagger \dagger} p<0.01,{ }^{\dagger \dagger} p<0.001 \mathrm{vs} 8.3 \mathrm{mmol} / 1$ glucose or as indicated investigate the effect of PKC activation on exocytosis elicited by trains of five 500 -ms depolarisations from -70 to $0 \mathrm{mV}$ (Fig. 2). PMA (10 nmol/l) augmented the exocytotic responses regardless of the magnitude of the responses under basal condition (Fig. 2a, b). The total capacitance increase evoked by the trains averaged $40 \pm 15$ $\mathrm{fF}(n=12)$ under control condition and $185 \pm 25 \mathrm{fF}(p<$ 0.001) (Fig. 2c) 6 min after addition of PMA. Exocytosis elicited by this stimulation paradigm reflects fusion of granules belonging to the readily releasable pool (RRP) and its replenishment from a reserve pool [13]. An upper estimate of RRP can be obtained from the sum of the capacitance increase elicited by the first two depolarisations of the train [36], whereas the response to the following three pulses was used to estimate exocytosis due to replenishment of RRP. The RRP was thus estimated to be $48 \pm 30 \mathrm{fF}(n=12)$ and $113 \pm 26 \mathrm{fF}(p<0.001)$ in the absence and presence of PMA, respectively. This was paralleled by a sixfold increase in membrane capacitance from $12 \pm 6 \mathrm{fF}$ $(n=12)$ to $75 \pm 14 \mathrm{fF}(p<0.001)$ in the response reflecting refilling of RRP.

To rule out the possibility that PMA stimulates alpha cell exocytosis by increased $\mathrm{Ca}^{2+}$ channel activity, we measured whole cell $\mathrm{Ca}^{2+}$ currents in response to depolarisations from the holding membrane potential $-70 \mathrm{mV}$ to membrane potentials ranging from -60 to $+50 \mathrm{mV}$. However, no effect of PMA on the peak current amplitude was observed (Fig. 2d).

Treatment with BIM suppresses pancreatic alpha cell exocytosis We next compared exocytosis in mouse alpha cells in the absence and presence of the PKC antagonist, BIM. In the majority of cells investigated (six out of nine cells), BIM reduced exocytosis evoked by a train of depolarisations (Fig. 3a). In these six cells, the total capacitance increase evoked by the train decreased from $138 \pm 15 \mathrm{fF}$ under control condition to $59 \pm 10 \mathrm{fF}(n=6 ; p<$ 0.05 ) (Fig. 3b) in the presence of BIM. Further analysis (see above) revealed that BIM reduced RRP by around $60 \%(p<$ 0.05 ) (Fig. 3b) and the capacitance response reflecting refilling by around $40 \%(p<0.05)$ (Fig. 3b). BIM did not affect exocytosis in the remaining three cells, in which exocytosis had already been low under control conditions (Fig. 3c).

We also measured whole cell $\mathrm{Ca}^{2+}$ currents in the presence and absence of BIM (Fig. 3d). In eight cells, the $\mathrm{Ca}^{2+}$ current was inhibited by about $30 \%(p<0.01)$.

Expression of genes encoding PKC isoforms in mouse and human islets We investigated the gene expression pattern of different PKC isoforms in mouse and human pancreatic islets using quantitative real-time PCR (Fig. 4). Genes encoding classical $\mathrm{PKC}$ isoforms ( $\mathrm{PKC} \alpha, \mathrm{PKC} \beta 1)$ were the 


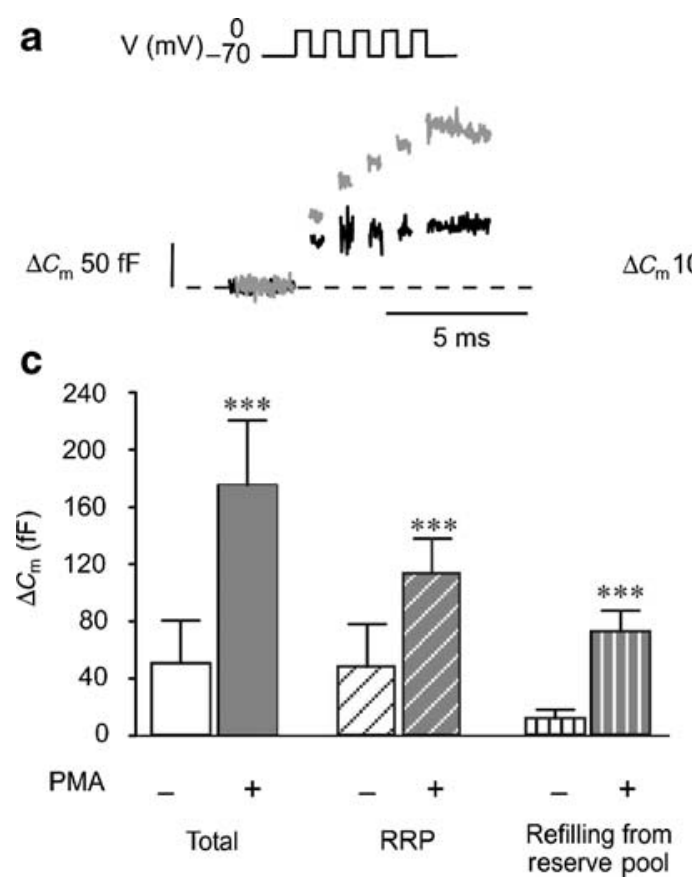

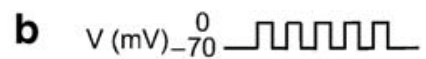

Fig. 2 PMA-dependent stimulation of exocytosis in single mouse alpha cells. a Capacitance increase elicited by a train of five $500 \mathrm{~ms}$ depolarisations from -70 to $0 \mathrm{mV}$ before (black trace) and 6 min after (grey trace) inclusion of $10 \mathrm{nmol} / \mathrm{l} \mathrm{PMA}$ in the extracellular solution. b Capacitance increase determined as above (a) for an alpha cell with a larger response in the absence of PMA. c Histogram summarising the average increase in cell membrane capacitance $\left(\Delta C_{\mathrm{m}}\right)$ evoked by all five depolarisations of the train, the first two depolarisations (RRP) and the following three depolarisations (refilling from reserve pool) in the presence and absence of PMA. d Peak $\mathrm{Ca}^{2+}$ current amplitude (I) against membrane potential (V) recorded before (white symbols) and after the addition of $10 \mathrm{nmol} / 1 \mathrm{PMA}$ in the extracellular solution (black symbols). Data are the mean $\pm \mathrm{SEM}$ of 12 paired experiments. $* * * p<0.001$ vs control most highly expressed in mouse, whereas those encoding the novel (PKC $\delta, \mathrm{PKC} \varepsilon, \mathrm{PKC} \eta \mathrm{PKC} \theta$ ) and atypical $\mathrm{PKC}$ ( $\mathrm{PKCl}, \mathrm{PKC \zeta}$ ) isoforms were more abundant in human islets.

Due to the extremely low expression of $P K C \beta 1$ (also known as $P R K C B$ or $P R K C B 1$ ) in human islets, we selected $\mathrm{PKC} \alpha$ for further analysis of activation and translocation of classical PKC isoforms in alpha cells. Among the novel PKC isoforms, $\mathrm{PKC} \delta$ and $\mathrm{PKC} \varepsilon$ were highly abundant in both species and have been described as being involved in exocytosis [28, 37]. We opted for PKC $\delta$ in our further study, since $\mathrm{PKC} \varepsilon$ staining showed very low levels by confocal immunocytochemistry in mouse alpha cells (data not shown).

PMA- and $\mathrm{Ca}^{2+}$-dependent translocation of PKCQ in mouse and human alpha cells The distribution of PKC $\alpha$ was analysed by confocal microscopy on single mouse and human alpha cells exposed to $1 \mathrm{mmol} / \mathrm{l}$ glucose (Figs 5 and 6), i.e. conditions associated with a high rate of glucagon secretion (Fig. 1). The identity of the alpha cells was established by immunoreactivity for glucagon. The translocation of PKC isoforms was quantified by calculating the ratio of the fluorescent intensity in the vicinity of the plasma membrane (within a distance of $0.5 \mu \mathrm{m}$ to the plasma membrane, $\left.I_{1}\right)$ to that in the inner cytosolic area $\left(I_{2}\right)$ as illustrated in Fig. 5c (details, see Methods).

In the absence of PMA, PKC $\alpha$ was located in the vicinity of the plasma membrane in about $90 \%$ of the mouse alpha cells (Fig. 5a, d), while only a few cells displayed cytosolic localisation (data not shown). This pattern did not change following stimulation with PMA (Fig. 5a, d).

Previous studies have shown that $\mathrm{PKC} \alpha$ is $\mathrm{Ca}^{2+}$ sensitive [38]. To determine whether the association of $\mathrm{PKC} \alpha$ with the plasma membrane observed in the presence of $1 \mathrm{mmol} / 1$ glucose alone is $\mathrm{Ca}^{2+}$-dependent, we treated mouse pancreatic cells with $400 \mu \mathrm{mol} / \mathrm{l}$ of the $\mathrm{K}_{\mathrm{ATP}}$ channel opener diazoxide or $2 \mu \mathrm{mol} / 1$ of the L-type $\mathrm{Ca}^{2+}$ channel inhibitor, isradipine, in the absence and presence of $1 \mu \mathrm{mol} / 1$ PMA. Confocal microscopy showed that exposure to diazoxide caused a re-distribution of $\mathrm{PKC} \alpha$ from the cell membrane to the cytosol and decreased the ratio $\left(I_{1} / I_{2}\right)$ by $50 \%(p<0.001)$ (Fig. $5 \mathrm{~b}, \mathrm{~d})$. In the presence of isradipine, the reduction of the ratio was $45 \%$ compared with control $(p<0.001)$ (Fig. 5b, d). Thus, the re-distribution to the cytosol by diazoxide can almost entirely be attributed to inhibition of $\mathrm{Ca}^{2+}$ entry via L-type $\mathrm{Ca}^{2+}$ channels. The isradipine-induced redistribution of $\mathrm{PKC} \alpha$ was counter- 


\section{a}

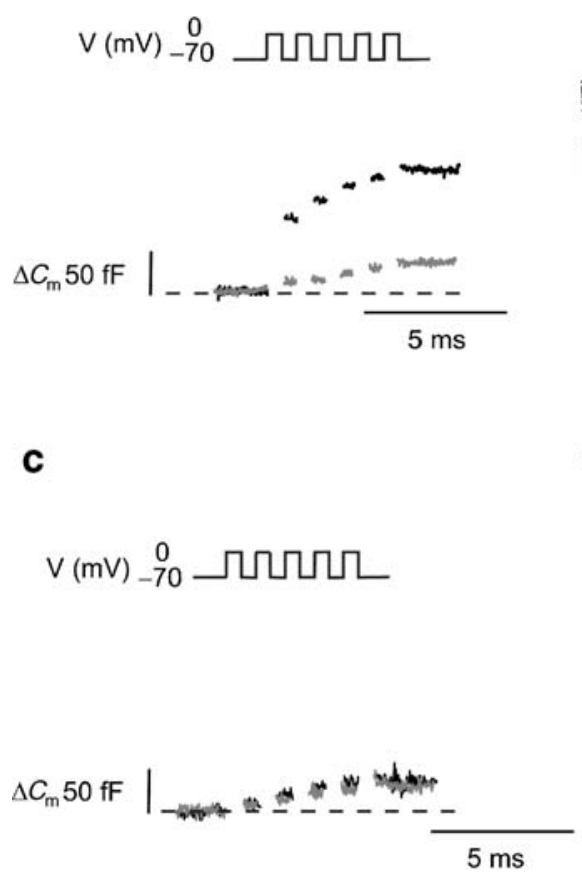

$5 \mathrm{~ms}$

Fig. 3 Inhibition of exocytosis and voltage-dependent $\mathrm{Ca}^{2+}$ currents by BIM. a Increase in membrane capacitance of a mouse alpha cell with a high exocytotic response under control conditions (black trace) and $6 \mathrm{~min}$ after (grey trace) inclusion of $2.4 \mu \mathrm{mol} / \mathrm{l} \mathrm{BIM}$ in the extracellular solution. Experiments were performed as described in the legend to Fig. 2. b Histogram summarising the average increase in cell membrane capacitance $\left(\Delta C_{\mathrm{m}}\right)$ measured during the experiment

acted when the cells were simultaneously exposed to PMA (Fig. 5b, d). The latter experiment demonstrates that the translocation of PKC $\alpha$ to the plasma membrane can be triggered independently, either by increased $\mathrm{Ca}^{2+}$ influx through L-type $\mathrm{Ca}^{2+}$ channels or by activation of PKC by PMA.

In contrast to the situation in mouse, $\operatorname{PKC} \alpha$ in human alpha cells principally located to the cytosol in the absence of PMA (Fig. 6a, c). PMA treatment translocated PKC $\alpha$ from the cytosol towards the cell periphery and the $I_{1} / I_{2}$ ratio increased around twofold $(p<0.001)$. The distribution of $\mathrm{PKC} \alpha$ in human alpha cells was not affected by diazoxide or isradipine (Fig. 6b, c), and PMA remained capable of triggering the translocation of $\mathrm{PKC} \alpha$ in the presence of isradipine (Fig. 6b, c).

Translocation and distribution of PKC $\delta$ in mouse and human alpha cells The distribution of PKC $\delta$ in the presence of $1 \mathrm{mmol} / 1$ glucose alone was cytosolic in mouse (Fig. 7) and human alpha cells (Fig. 8). PMA stimulated translocation of PKC $\delta$ from the cytosol towards the plasma membrane, and $I_{1} / I_{2}$ ratio increased 1.5 -fold in mouse $(p<$
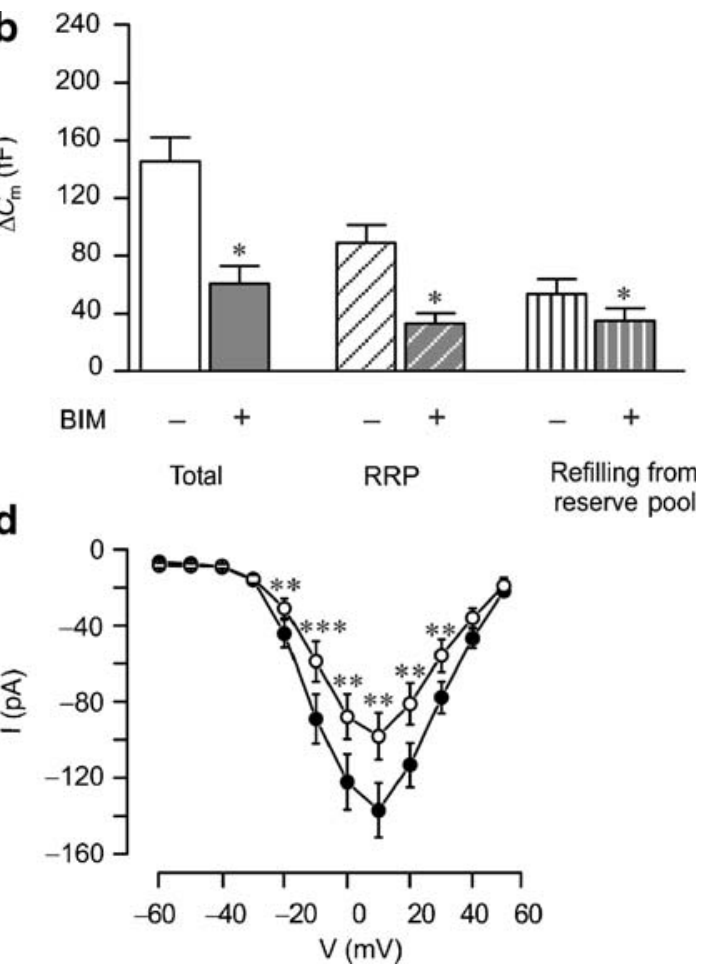

described in part a. c Capacitance increase in a mouse alpha cell where BIM had no further effect. d Peak $\mathrm{Ca}^{2+}$ current amplitude (I) against membrane potential $(\mathrm{V})$ recorded before (black symbols) and after addition of $2.4 \mu \mathrm{mol} / \mathrm{l} \mathrm{BIM}$ to the extracellular solution (white symbols). Data are mean \pm SEM of six to eight paired experiments. ${ }^{*} p<0.05, * * p<0.01, * * * p<0.001$ vs control

0.01) (Fig. 7a, c) and twofold in human alpha cells $(p<$ 0.001) (Fig. 7a, c).

Although PKC $\delta$, unlike the conventional PKCs, does not have a $\mathrm{Ca}^{2+}$-sensing $\mathrm{C} 2$ domain, we examined the impact of diazoxide and isradipine in the presence or absence of PMA stimulation on the distribution of this isoenzyme (Figs 7 and 8). Neither diazoxide nor isradipine changed the distribution of $\mathrm{PKC} \delta$ in mouse (Fig. 7b, c) or human (Fig. 8b, c) alpha cells, suggesting that the translocation of $\mathrm{PKC} \delta$ is $\mathrm{Ca}^{2+}$-independent. PMA stimulated $\mathrm{PKC} \delta$ translocation towards the plasma membrane even in the presence of isradipine (Figs 7b, c, 8b, c).

\section{Discussion}

Glucagon is released by regulated exocytosis initiated by an increase in intracellular $\mathrm{Ca}^{2+}$ concentration $[6,13]$. Protein phosphorylation by protein kinases such as PKC plays an important modulatory role in exocytosis in beta cells [39] and is known to augment exocytosis in a variety of diverse secretory cells $[23-25,39,40]$. Here we have investigated 

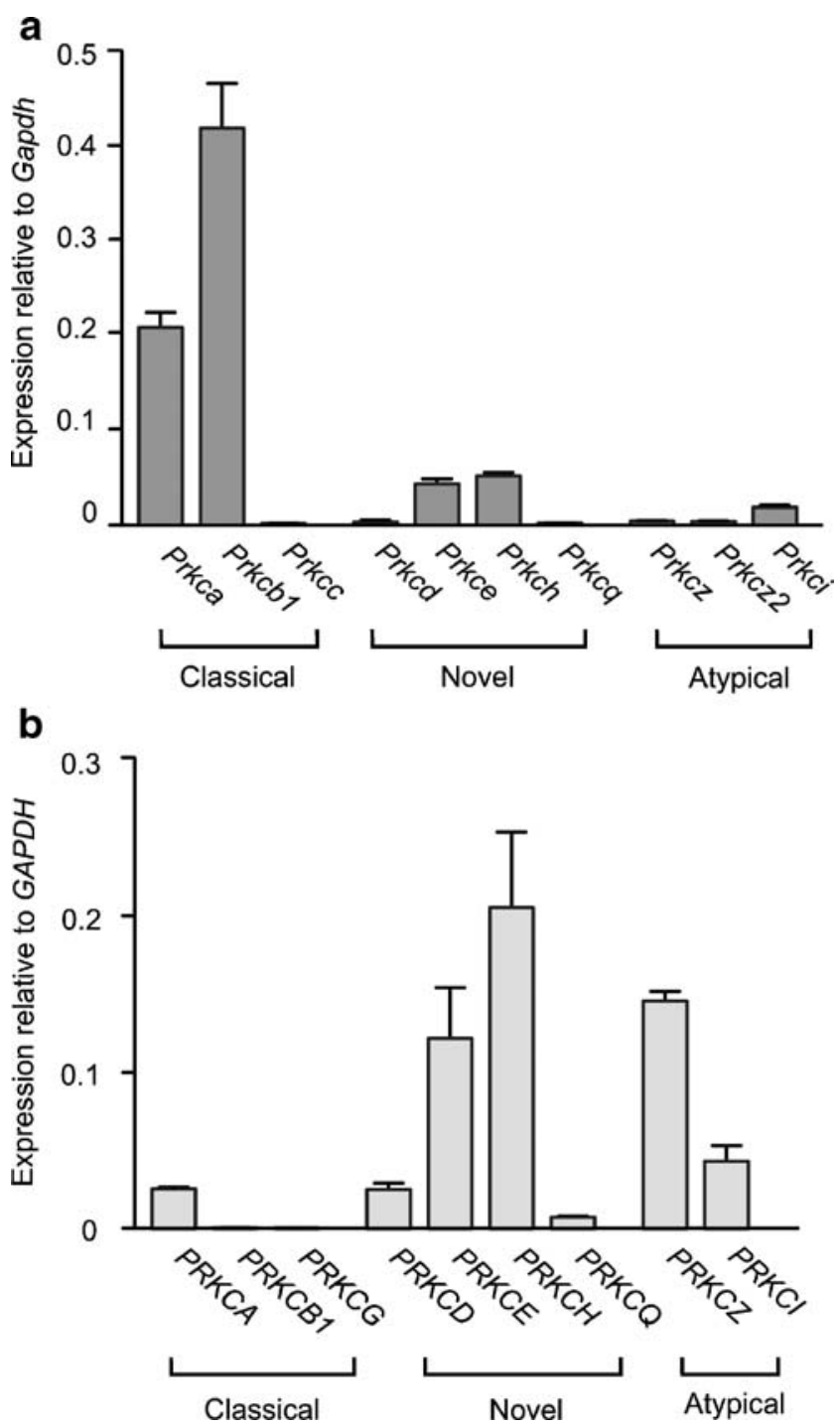

Fig. 4 Expression of genes encoding PKC isoforms in (a) mouse and (b) human islets. Relative quantitative real-time PCR was performed on mouse islets (a) and human islets (b) to measure gene expression of the PKC isoforms

the role of PKC in alpha cell exocytosis and also the translocation of $\mathrm{PKC} \alpha$ and $\mathrm{PKC} \delta$ upon stimulation by the diacylglycerol analogue, PMA.

The PKC-activator, PMA, strongly stimulated glucagon secretion in mouse and human islets (Fig. 1). This is in accordance with a previous report on rat islets [15]. Capacitance measurements confirmed the glucagon release data and showed that PMA enhanced depolarisation-evoked exocytosis fivefold without affecting the magnitude of the $\mathrm{Ca}^{2+}$ current (Fig. 2a, d). This is reminiscent of our previous observations in insulin-secreting beta cells [39] and suggests that PKC stimulates glucagon secretion at a late stage exerted at the level of exocytosis itself. Analysis of the responses to the individual depolarisations indicates that PMA increased the size and refilling of RRP, and that
BIM had the opposite effects. Thus, PKC activation exerts a dual role. This is in agreement with earlier studies on chromaffin cells [36, 41]. Munc-18 is one of the central proteins involved at several levels in the exocytotic process [30] and has been shown to be phosphorylated by PKC [32]. Indeed, all our data on alpha cells are consistent with a scenario in which PKC-dependent phosphorylation of munc-18 promotes fusion, priming and docking of granules.

BIM inhibits PKC activity by competitive binding to the ATP-binding site of the catalytic domain [42]. Our patchclamp measurements revealed that BIM, in addition to inhibiting depolarisation-evoked exocytosis by around $60 \%$ (Fig. 3a), reduced the $\mathrm{Ca}^{2+}$ current by $30 \%$ (Fig. 3d). Thus, the reduced exocytotic response can be due to a combination of (1) direct inhibition of exocytosis as such and (2) reduction of $\mathrm{Ca}^{2+}$-induced exocytosis, which is secondary to inhibited $\mathrm{Ca}^{2+}$ influx. It remains to be determined whether the effect of BIM on the $\mathrm{Ca}^{2+}$ current is mediated by inactivation of PKC or is a direct inhibitory action of the compound on $\mathrm{Ca}^{2+}$ channel activity. Indeed, it has been demonstrated that BIM directly (i.e. not through inhibition of PKC activity) reduces voltage-dependent $\mathrm{K}^{+}$-channel currents in other cell types [43, 44]. Interestingly, the changes in the magnitude of the $\mathrm{Ca}^{2+}$ current were only obtained with BIM. In this context, we stress that PMA was without effect on the $\mathrm{Ca}^{2+}$ current (Fig. 2d). Thus, increased $\mathrm{Ca}^{2+}$ current is not necessary for PMA-stimulated exocytosis, and once PKC is activated by PMA, translocation not only of $\mathrm{PKC} \delta$, but also of $\mathrm{PKC} \alpha$ can occur independently of $\mathrm{Ca}^{2+}$ influx (Figs $4 b, 5 b$ ).

It has been shown that PKC increases its membrane affinity upon stimulation. Activation of PKC by diacylglycerol or PMA induces translocation of PKC from the cytoplasm to the plasma membrane [45]. Indeed, $\mathrm{PKC} \delta$ translocated from cytosol to cell periphery upon PMA stimulation in mouse and human alpha cells (Figs 7 and 8). This re-distribution places $\mathrm{PKC} \delta$ in close proximity to any downstream substrates involved in exocytosis. Our data indicate that translocation of PKC $\delta$ is $\mathrm{Ca}^{2+}$-independent, which is in agreement with a previous report that translocation of novel PKCs like PKC $\delta$ depends solely on binding of diacylglycerol to the $\mathrm{C} 1$ domains of PKC $\delta$ [46].

Interestingly, the translocation pattern of $\mathrm{PKC} \alpha$ differs between mouse and human alpha cells. In mouse alpha cells, $\mathrm{PKC} \alpha$ is preferentially located in the vicinity of the plasma membrane when exposed to glucose alone at concentrations as low as $1 \mathrm{mmol} / 1$ (Fig. 5a), while activation by PMA was necessary for the translocation of $\mathrm{PKC} \alpha$ to the cell membrane in human alpha cells (Fig. 6a). This echoes the effect of BIM on glucagon secretion at $1 \mathrm{mmol} / \mathrm{l}$ glucose, which was only affected in mouse islets (Fig. 1b). It is tempting to speculate that this is a reflection 
Fig. 5 Distribution of $\mathrm{PKC} \alpha$ in mouse alpha cells. a Confocal immunostaining of single alpha cells subjected to incubation in the absence (control) or presence of $1 \mu \mathrm{mol} / 1$ PMA as indicated. Cells were labelled with antibodies against $\mathrm{PKC} \alpha$ (green) and glucagon (purple), and individual images of these merged. Pancreatic alpha cells were identified by glucagon counterstaining. b Treatment as in part $\mathbf{a}$, except that cells were subjected to incubation with $400 \mu \mathrm{mol} / \mathrm{l}$ diazoxide, $2 \mu \mathrm{mol} / 1$ isradipine or isradipine in combination with $1 \mu \mathrm{mol} / 1$ PMA as indicated. Scale bars $2 \mu \mathrm{m}$; representative images of 10 to 15 scanned fields are presented. $\mathbf{c}$ Illustration of the areas used to calculate $\mathrm{PKC} \alpha$ distribution ratio $\left(I_{1} / I_{2}\right.$, see Methods). d Quantification of the distribution of $\mathrm{PKC} \alpha$ in mouse alpha cells. Ctrl, control; Dia, diazoxide; Isr, isradipine. $* p<0.05$ vs in presence of diazoxide. ${ }^{* *} p<0.001$ vs control a

Control

PMA

b

Diazoxide

Isradipine

Isradipine

+ PMA
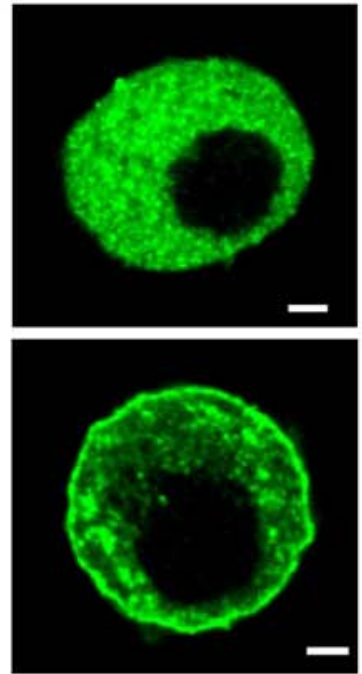

C
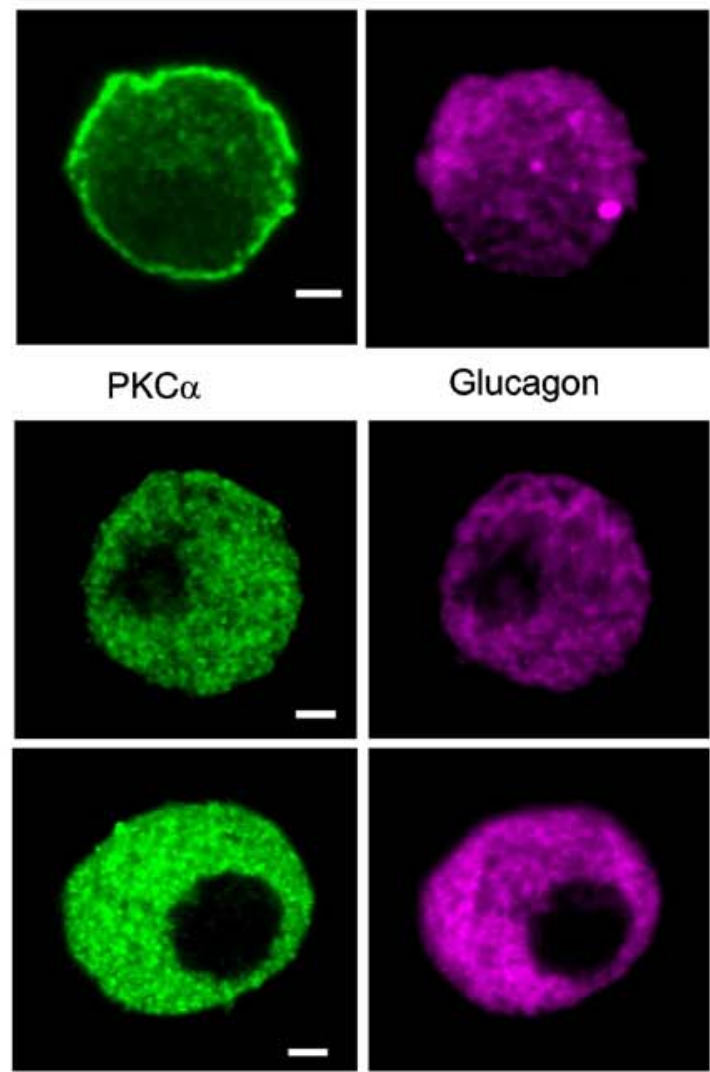

$\mathrm{PKC} \alpha$

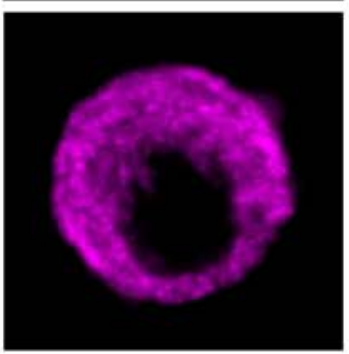

d
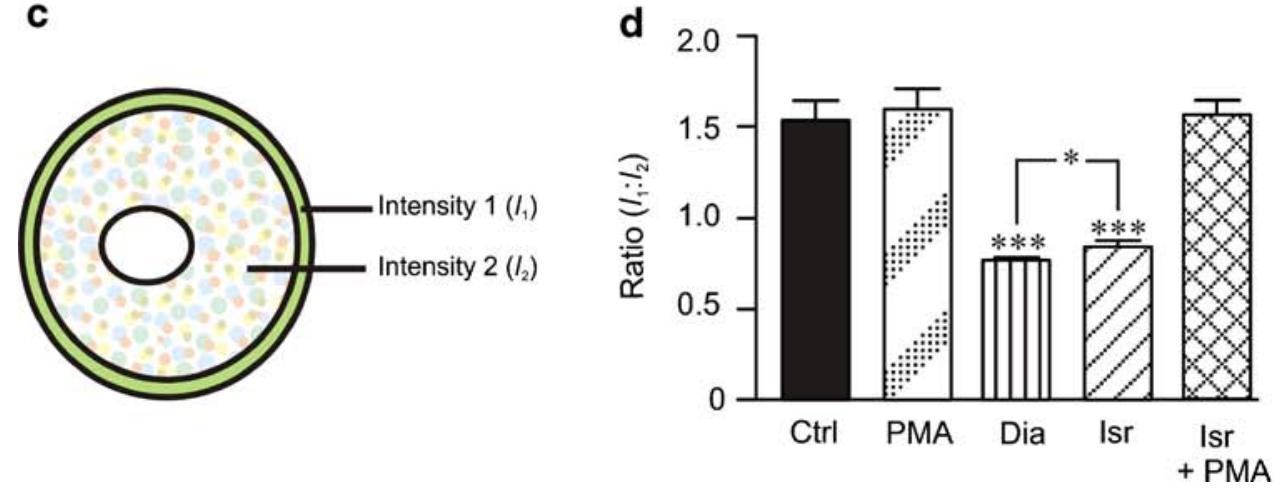

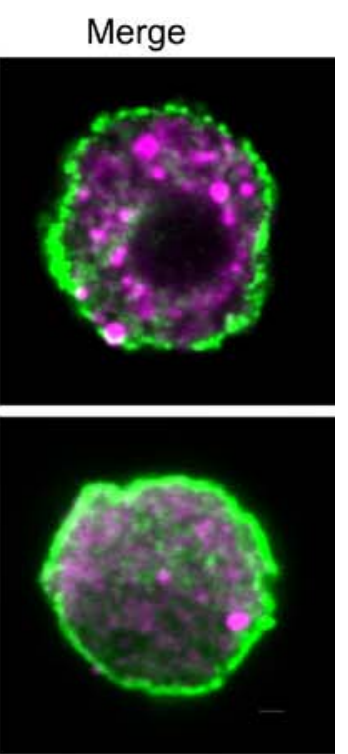

Merge
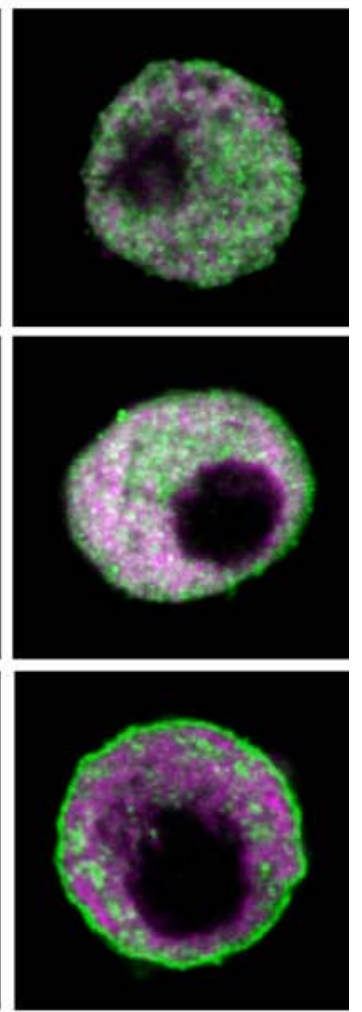
Fig. 6 Distribution of $\mathrm{PKC} \alpha$ in human alpha cells. a, b Experiments as in Fig. 5a, b, but performed on human samples. Scale bars $2 \mu \mathrm{m}$, representative images of 10 to 15 scanned fields are presented. c Quantification of the distribution of $\mathrm{PKC} \alpha$ in human alpha cells. Ctrl, control; Dia, diazoxide; Isr, isradipine. ${ }^{* * *} p<0.001 \mathrm{vs}$ control a

Control

PMA

b

Diazoxide

sradipine

Isradipine

+ PMA

C
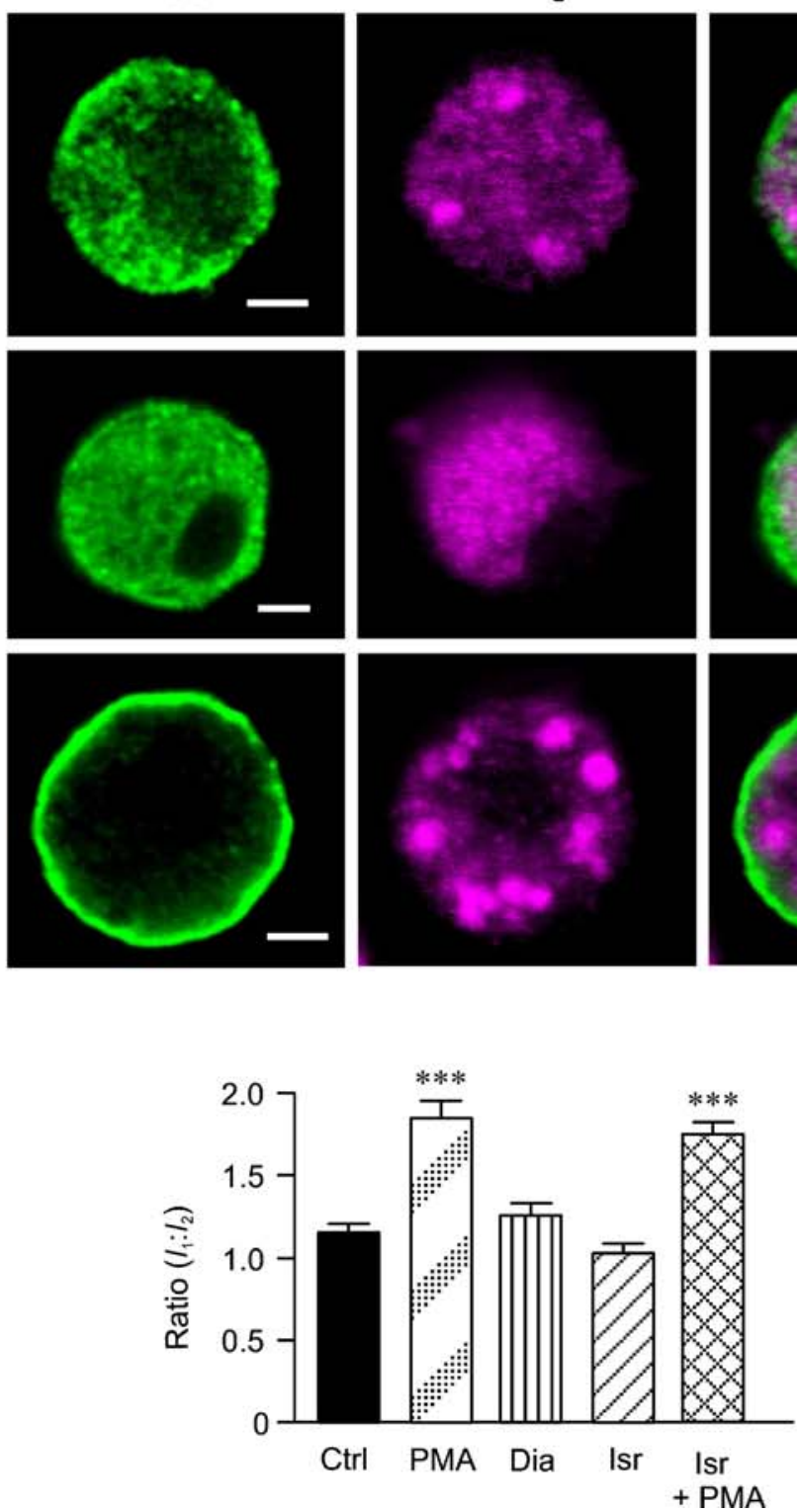

Merge
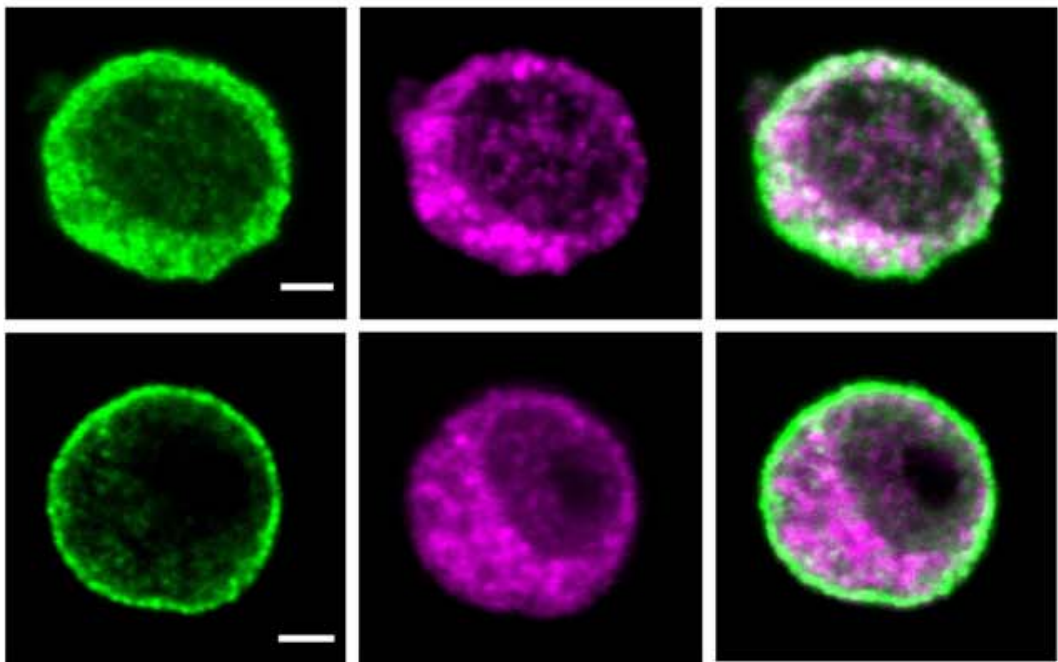

$\mathrm{PKC} \alpha$

Glucagon

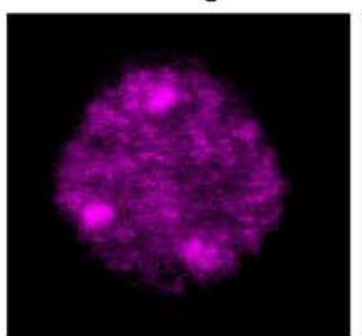

Merge
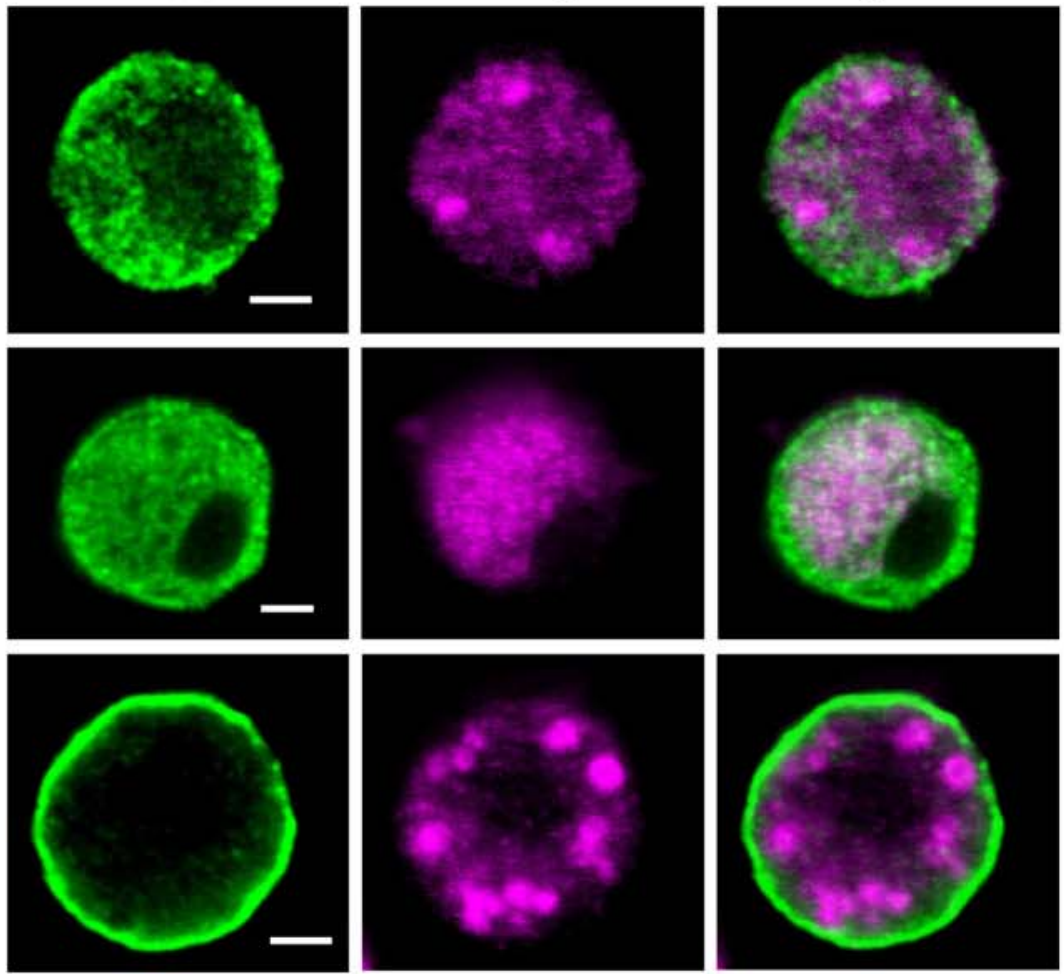
Fig. 7 Distribution of $\mathrm{PKC} \delta$ in mouse alpha cells. a Confocal immunostaining of cells dispersed from single islets from mouse as in Fig. 5a, except that cells were labelled with antibodies against $\mathrm{PKC} \delta$ (green) as indicated. b Treatment as in part a, but performed in the presence of $400 \mu \mathrm{mol} / 1$ diazoxide, $2 \mu \mathrm{mol} / 1$ isradipine or isradipine in combination with $1 \mu \mathrm{mol} / 1$ PMA as shown. Scale bars $2 \mu \mathrm{m}$; representative images of 10 to 15 scanned fields are presented. c Quantification of the distribution of PKC $\delta$ in mouse alpha cells. Ctrl, control; Dia, diazoxide; Isr, isradipine. $* * * p<0.001 \mathrm{vs}$ control a

Control

PMA

b

Diazoxide

Isradipine

Isradipine

+ PMA
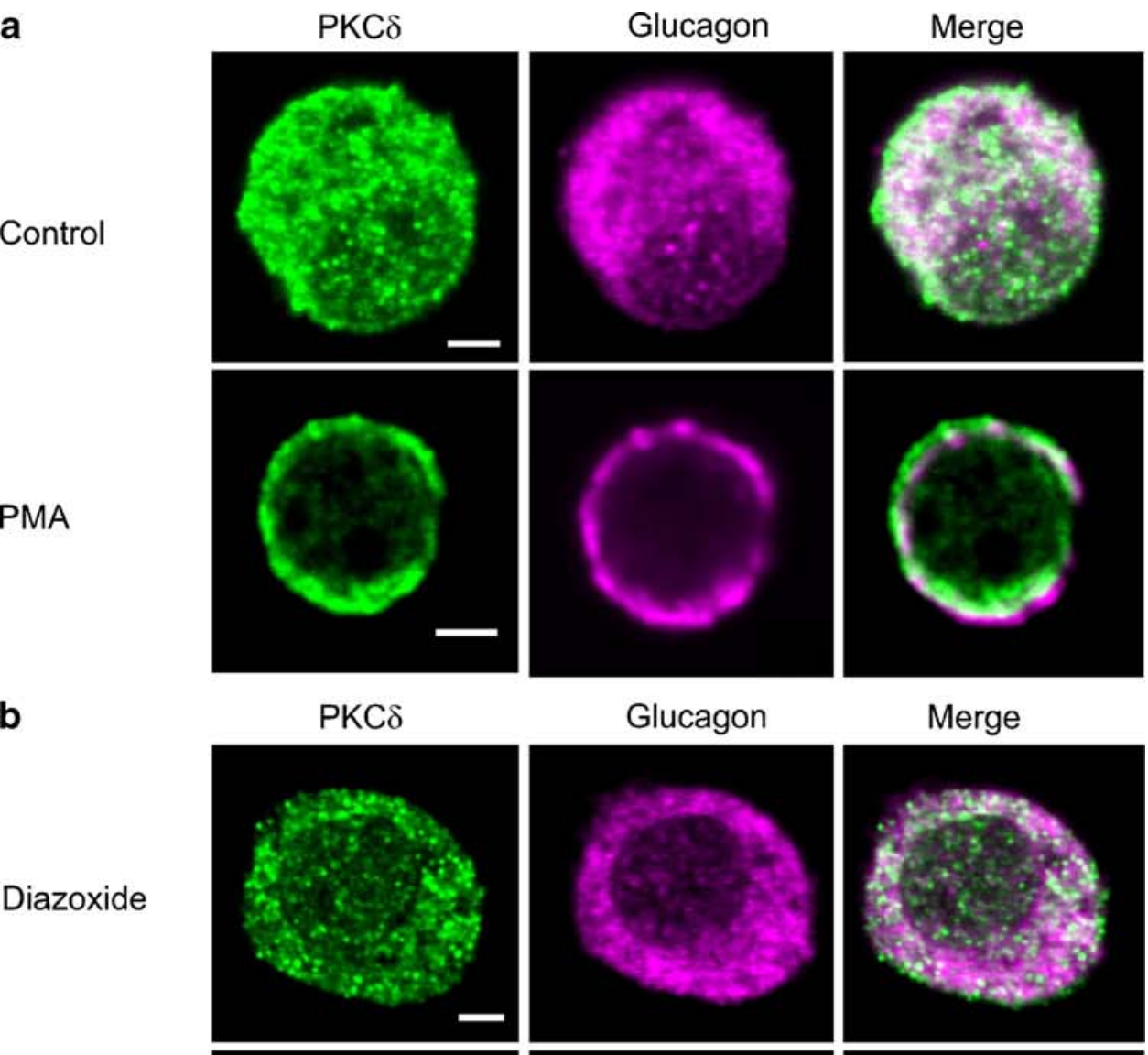

Glucagon

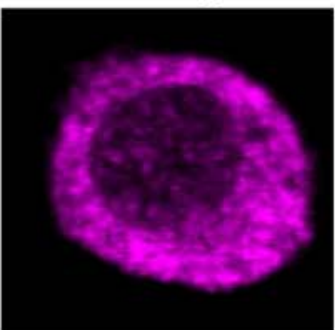

Merge
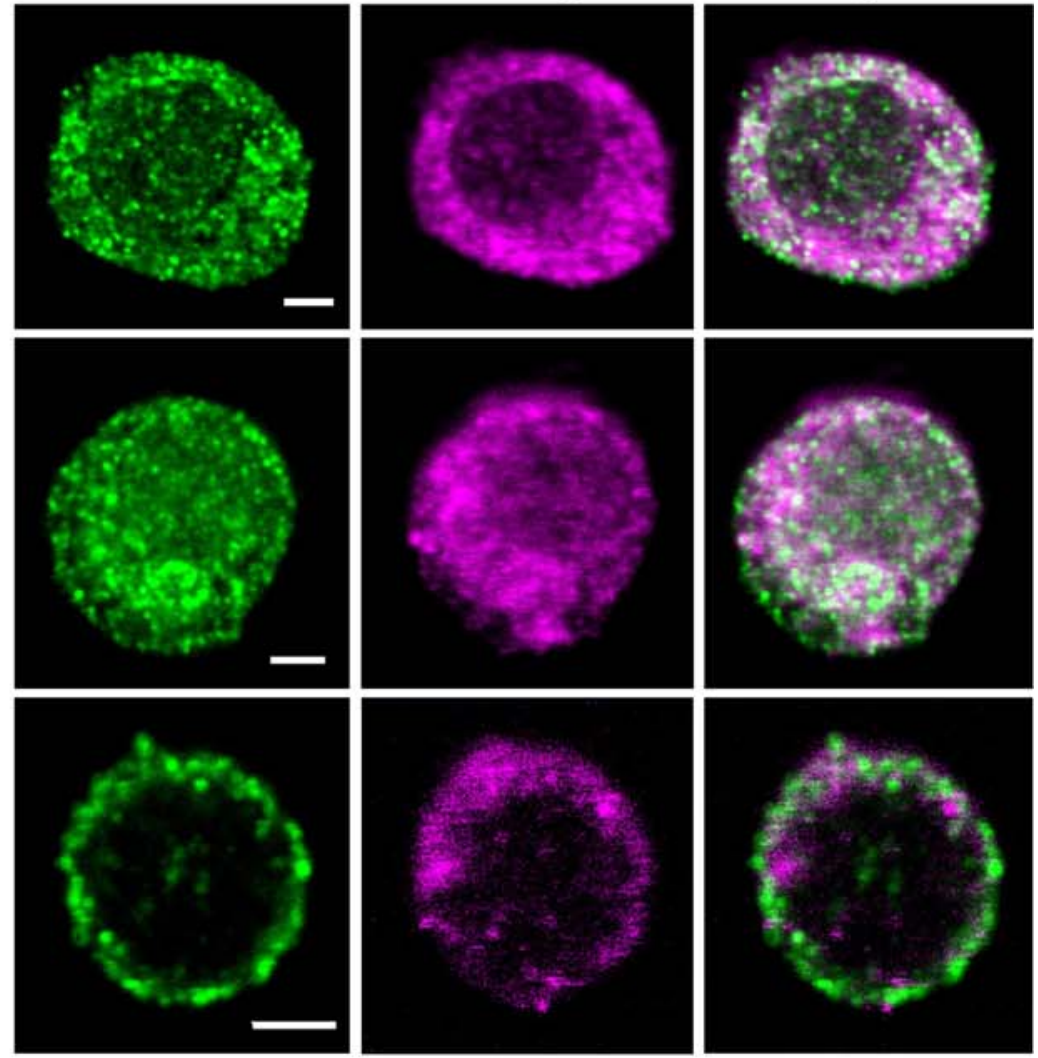

C

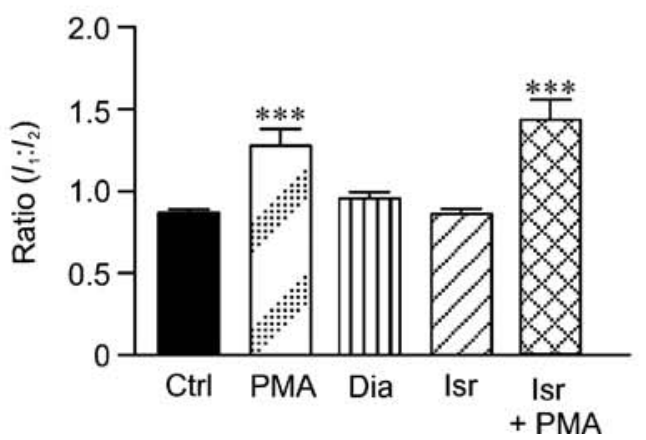


Fig. 8 Distribution of PKC $\delta$ in human alpha cells. a, b As in Fig $7 \mathrm{a}, \mathrm{b}$, except that experiments were performed on human alpha cells. Scale bars $2 \mu \mathrm{m}$, representative images of 10 to 15 scanned fields are presented. c Quantification of the distribution of PKC $\delta$ in human alpha cells. Ctrl, control; Dia, diazoxide; Isr, isradipine. $* * * p<0.001$ vs control a
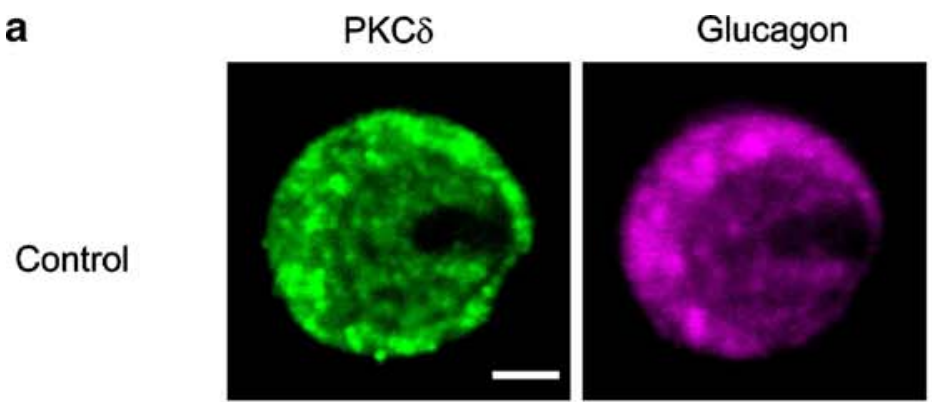

b

PMA

Diazoxide

Isradipine

\section{Isradipine + PMA}

C
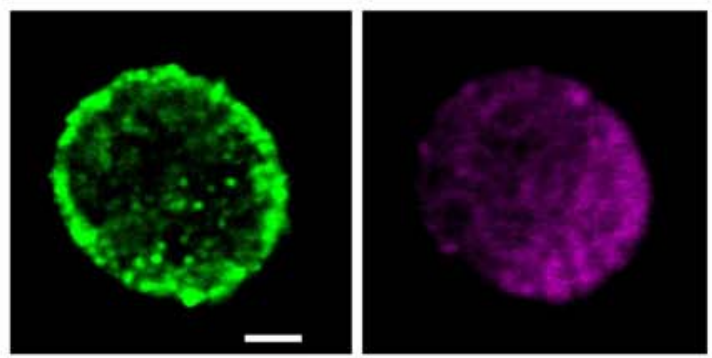

Glucagon
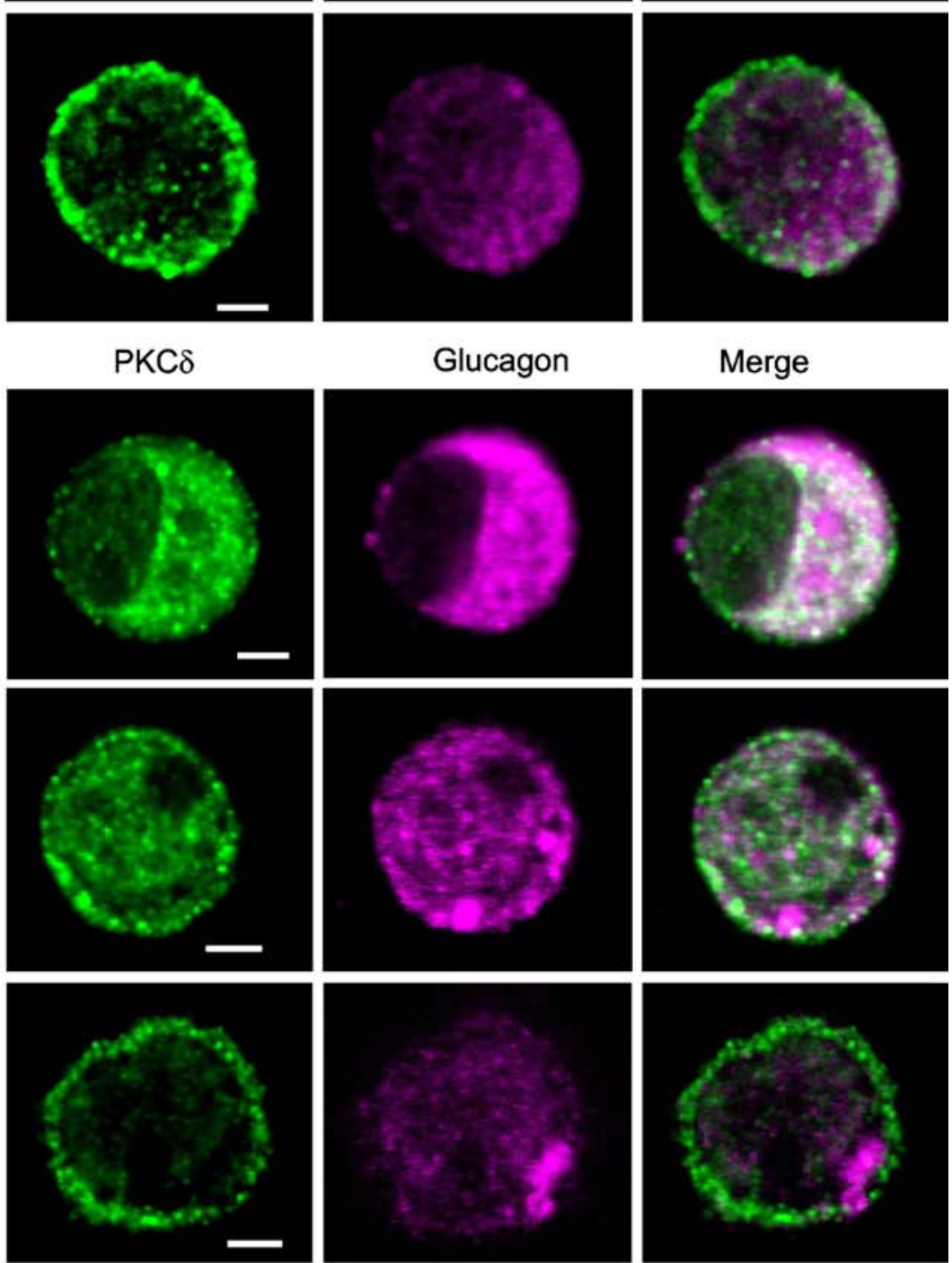

Merge
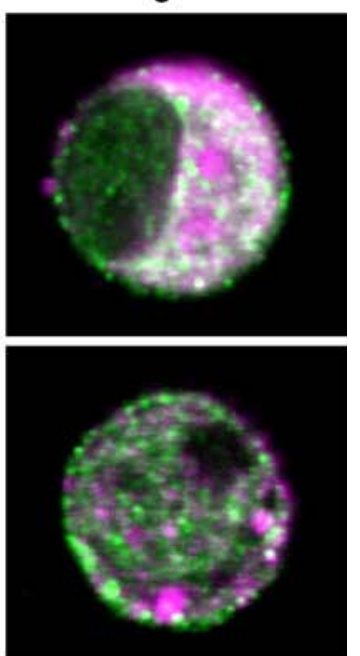

Merge
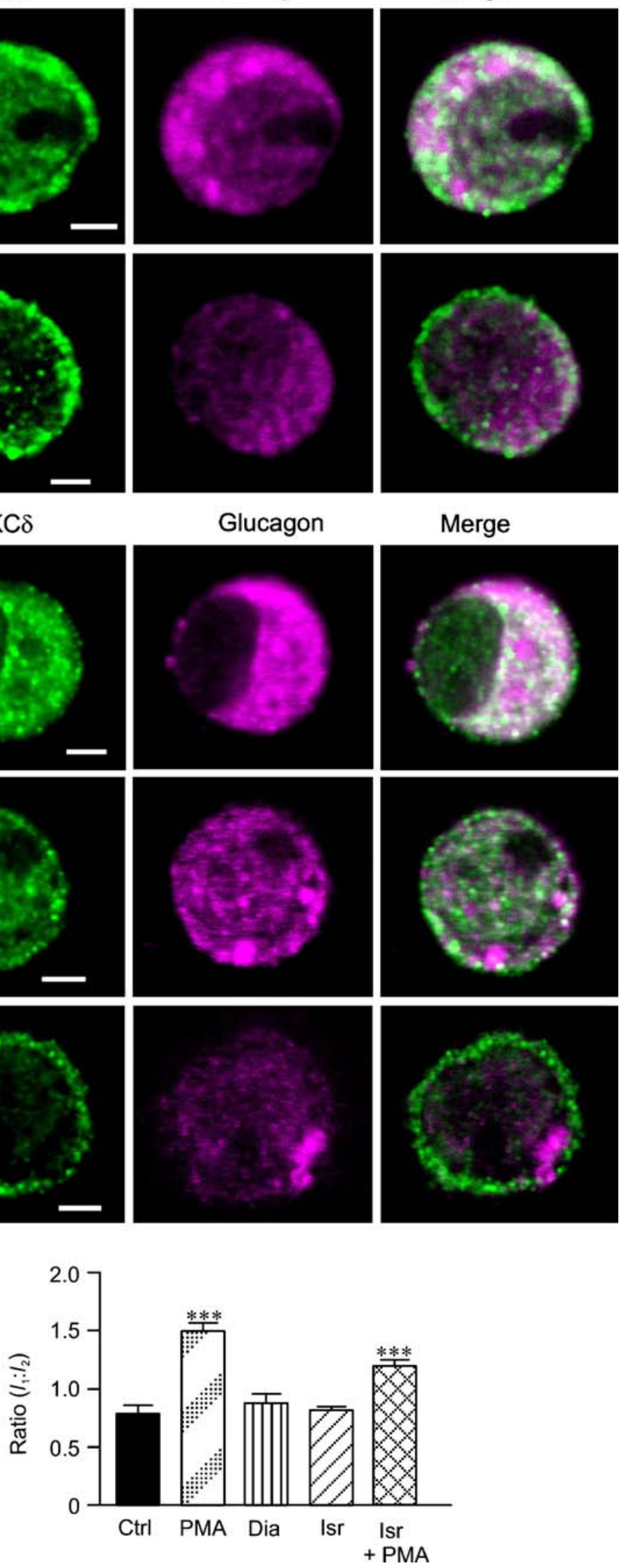
of PKC $\alpha$ being tonically activated in mouse alpha cells and thereby susceptible to inhibition by BIM. PKC $\alpha$, which belongs to the classical PKCs, is activated by increased intracellular $\mathrm{Ca}^{2+}$ and diacylglycerol [46]. In beta cells, glucose has been reported to produce a $\mathrm{Ca}^{2+}$-dependent translocation of classical PKCs to the plasma membrane [29]. In mouse alpha cells, we attribute the near-plasma membrane localisation of PKC $\alpha$ in the absence of PMA to the high $\left[\mathrm{Ca}^{2+}\right]_{\mathrm{i}}$ resulting from $\mathrm{Ca}^{2+}$ influx through $\mathrm{Ca}^{2+}$ channels, which are activated during the action potentials generated at low glucose. This scenario is suggested by the redistribution of $\mathrm{PKC} \alpha$ to the cytosolic region in cells exposed to diazoxide or isradipine (Fig. 5b). We demonstrated that $\mathrm{Ca}^{2+}$ influx through the L-type $\mathrm{Ca}^{2+}$ channel is the major source $(90 \%)$ responsible for the $\mathrm{Ca}^{2+}$-dependent translocation of $\mathrm{PKC} \alpha$, while only $10 \%$ of the translocation is due to $\mathrm{Ca}^{2+}$ influx through other channels. We can only speculate about why this does not occur in human alpha cells, but it may be pertinent that distribution of PKC $\alpha$ is less peripheral in human than in mouse alpha cells (Figs 5 and 6). It is possible that in human alpha cells, the intracellular $\mathrm{Ca}^{2+}$ concentration is lower than in mouse alpha cells [47, 48], resulting in translocation of $\mathrm{PKC} \alpha$ to the plasma membrane in a less $\mathrm{Ca}^{2+}$-dependent manner. This explanation would also account for the greater sensitivity to PMA.

Glucagon secretion and exocytosis in the pancreatic alpha cell triggered by low glucose alone is dependent on influx through the N-type $\mathrm{Ca}^{2+}$ channel [14]. Although L-type $\mathrm{Ca}^{2+}$ channels are not essential for exocytosis in alpha cells in the absence of high concentrations of cyclic AMP, the data presented here indicate that these channels mediate the $\mathrm{Ca}^{2+}$ influx that induces the $\mathrm{Ca}^{2+}$-dependent translocation of $\mathrm{PKC} \alpha$ to the plasma membrane. Thus, $\mathrm{L}$ - and $\mathrm{N}$-type $\mathrm{Ca}^{2+}$ channels fulfil different functions in the alpha cell (PKC translocation and exocytosis, respectively). We finally point out that elevation of intracellular cyclic AMP causes an interesting switch in $\mathrm{Ca}^{2+}$ channel dependence and that in the presence of forskolin or adrenaline, L-type $\mathrm{Ca}^{2+}$ channels account for most of the $\mathrm{Ca}^{2+}$ entry involved in exocytosis [6]. Further studies are required to elucidate the interaction between cyclic AMP/PKA- and PKC-mediated effects on exocytosis, and how they depend on $\mathrm{Ca}^{2+}$ influx and PKC translocation. Clearly, the control of alpha cell exocytosis is very complex, making it easy to envisage disturbances capable of causing defective regulation of glucagon secretion, which is a hallmark of type 2 diabetes [49].

Acknowledgements We thank B.-M. Nilsson (Lund University Diabetes Centre) for expert technical assistance. This work was supported by the Swedish Research Council, EU-Biosim, the Knut and Alice Wallenberg foundation, the Crafoord foundation, the Thurings foundation, the Novo Nordisk Foundation and the Albert Påhlssons Foundation. P. Rorsman is supported by the Welcome Trust and the Medical Research Council. L. Eliasson and E. Renström are Swedish Research Council senior researchers.

Duality of interest The authors declare that there is no duality of interest associated with this manuscript.

\section{References}

1. Lins PE, Wajngot A, Adamson U, Vranic M, Efendic S (1983) Minimal increases in glucagon levels enhance glucose production in man with partial hypoinsulinemia. Diabetes 32:633-636

2. Myers SR, Diamond MP, Adkins-Marshall BA, Williams PE, Stinsen R, Cherrington AD (1991) Effects of small changes in glucagon on glucose production during a euglycemic, hyperinsulinemic clamp. Metabolism 40:66-71

3. Cryer PE (2004) Diverse causes of hypoglycemia-associated autonomic failure in diabetes. N Engl J Med 350:2272-2279

4. Shah P, Vella A, Basu A, Basu R, Schwenk WF, Rizza RA (2000) Lack of suppression of glucagon contributes to postprandial hyperglycemia in subjects with type 2 diabetes mellitus. J Clin Endocrinol Metab 85:4053-4059

5. Gromada J, Franklin I, Wollheim CB (2007) Alpha-cells of the endocrine pancreas: 35 years of research but the enigma remains. Endocr Rev 28:84-116

6. Gromada J, Bokvist K, Ding WG et al (1997) Adrenaline stimulates glucagon secretion in pancreatic A-cells by increasing the $\mathrm{Ca}^{2+}$ current and the number of granules close to the L-type $\mathrm{Ca}^{2+}$ channels. J Gen Physiol 110:217-228

7. Vieira E, Liu YJ, Gylfe E (2004) Involvement of alpha1 and betaadrenoceptors in adrenaline stimulation of the glucagon-secreting mouse alpha-cell. Naunyn Schmiedebergs Arch Pharmacol 369: 179-183

8. Dunning BE, Foley JE, Ahren B (2005) Alpha cell function in health and disease: influence of glucagon-like peptide-1. Diabetologia 48:1700-1713

9. Gromada J, Hoy M, Buschard K, Salehi A, Rorsman P (2001) Somatostatin inhibits exocytosis in rat pancreatic alpha-cells by $G$ (i2)-dependent activation of calcineurin and depriming of secretory granules. J Physiol 535:519-532

10. Ma X, Zhang Y, Gromada J et al (2005) Glucagon stimulates exocytosis in mouse and rat pancreatic alpha-cells by binding to glucagon receptors. Mol Endocrinol 19:198-212

11. Gopel S, Zhang Q, Eliasson L et al (2004) Capacitance measurements of exocytosis in mouse pancreatic alpha-, beta- and deltacells within intact islets of Langerhans. J Physiol 556:711-726

12. Rorsman P, Hellman B (1988) Voltage-activated currents in guinea pig pancreatic alpha 2 cells. Evidence for $\mathrm{Ca} 2+$-dependent action potentials. J Gen Physiol 91:223-242

13. Barg S, Galvanovskis J, Gopel SO, Rorsman P, Eliasson L (2000) Tight coupling between electrical activity and exocytosis in mouse glucagon-secreting alpha-cells. Diabetes 49:1500-1510

14. MacDonald PE, De Marinis YZ, Ramracheya R et al (2007) A K ATP channel-dependent pathway within alpha cells regulates glucagon release from both rodent and human islets of Langerhans. PLoS Biol 5:e143

15. Hii CS, Stutchfield J, Howell SL (1986) Enhancement of glucagon secretion from isolated rat islets of Langerhans by phorbol 12-myristate 13-acetate. Biochem J 233:287-289

16. Bjaaland T, Hii CS, Jones PM, Howell SL (1988) Role of protein kinase $\mathrm{C}$ in arginine-induced glucagon secretion from isolated rat islets of Langerhans. J Mol Endocrinol 1:105-110

17. Shirai Y, Saito N (2002) Activation mechanisms of protein kinase $\mathrm{C}$ : maturation, catalytic activation, and targeting. J Biochem 132:663-668 
18. Wolf BA, Easom RA, Hughes JH, McDaniel ML, Turk J (1989) Secretagogue-induced diacylglycerol accumulation in isolated pancreatic islets. Mass spectrometric characterization of the fatty acyl content indicates multiple mechanisms of generation. Biochemistry 28:4291-4301

19. Malaisse WJ, Dunlop ME, Mathias PC, Malaisse-Lagae F, Sener A (1985) Stimulation of protein kinase $C$ and insulin release by 1-oleoyl-2-acetyl-glycerol. Eur J Biochem 149:23-27

20. Zawalich W, Brown C, Rasmussen H (1983) Insulin secretion: combined effects of phorbol ester and A23187. Biochem Biophys Res Commun 117:448-455

21. Stutchfield J, Jones PM, Howell SL (1986) The effects of polymyxin $\mathrm{B}$, a protein kinase $\mathrm{C}$ inhibitor, on insulin secretion from intact and permeabilized islets of Langerhans. Biochem Biophys Res Commun 136:1001-1006

22. Easom RA, Hughes JH, Landt M, Wolf BA, Turk J, McDaniel ML (1989) Comparison of effects of phorbol esters and glucose on protein kinase $\mathrm{C}$ activation and insulin secretion in pancreatic islets. Biochem J 264:27-33

23. Hille B, Billiard J, Babcock DF, Nguyen T, Koh DS (1999) Stimulation of exocytosis without a calcium signal. J Physiol 520 (Pt 1):23-31

24. Turner KM, Burgoyne RD, Morgan A (1999) Protein phosphorylation and the regulation of synaptic membrane traffic. Trends Neurosci 22:459-464

25. Leenders AG, Sheng ZH (2005) Modulation of neurotransmitter release by the second messenger-activated protein kinases: implications for presynaptic plasticity. Pharmacol Ther 105:69-84

26. Hoy M, Berggren PO, Gromada J (2003) Involvement of protein kinase $\mathrm{C}$-epsilon in inositol hexakisphosphate-induced exocytosis in mouse pancreatic beta-cells. J Biol Chem 278:35168-35171

27. Ganesan S, Calle R, Zawalich K et al (1992) Immunocytochemical localization of alpha-protein kinase $\mathrm{C}$ in rat pancreatic beta-cells during glucose-induced insulin secretion. J Cell Biol 119:313-324

28. Uchida T, Iwashita N, Ohara-Imaizumi M et al (2007) Protein kinase Cdelta plays a non-redundant role in insulin secretion in pancreatic beta cells. J Biol Chem 282:2707-2716

29. Yedovitzky M, Mochly-Rosen D, Johnson JA et al (1997) Translocation inhibitors define specificity of protein kinase C isoenzymes in pancreatic beta-cells. J Biol Chem 272:1417-1420

30. Toonen RF, Verhage M (2007) Munc18-1 in secretion: lonely Munc joins SNARE team and takes control. Trends Neurosci 30:564-572

31. Craig TJ, Evans GJ, Morgan A (2003) Physiological regulation of Munc18/nSec1 phosphorylation on serine-313. J Neurochem 86: 1450-1457

32. Barclay JW, Craig TJ, Fisher RJ et al (2003) Phosphorylation of Munc18 by protein kinase $C$ regulates the kinetics of exocytosis. J Biol Chem 278:10538-10545

33. Amisten S, Braun OO, Bengtsson A, Erlinge D (2008) Gene expression profiling for the identification of G-protein coupled receptors in human platelets. Thromb Res 122:47-57
34. Pfaffl MW (2001) A new mathematical model for relative quantification in real-time RT-PCR. Nucleic Acids Res 29:e45

35. Salehi A, Vieira E, Gylfe E (2006) Paradoxical stimulation of glucagon secretion by high glucose concentrations. Diabetes 55:2318-2323

36. Gillis KD, Mossner R, Neher E (1996) Protein kinase C enhances exocytosis from chromaffin cells by increasing the size of the readily releasable pool of secretory granules. Neuron 16:12091220

37. Mendez CF, Leibiger IB, Leibiger B et al (2003) Rapid association of protein kinase $\mathrm{C}$-epsilon with insulin granules is essential for insulin exocytosis. J Biol Chem 278:44753-44757

38. Nishizuka Y (1984) The role of protein kinase C in cell surface signal transduction and tumour promotion. Nature 308:693-698

39. Ammala C, Eliasson L, Bokvist K et al (1994) Activation of protein kinases and inhibition of protein phosphatases play a central role in the regulation of exocytosis in mouse pancreatic beta cells. Proc Natl Acad Sci USA 91:4343-4347

40. Lindau M, Gomperts BD (1991) Techniques and concepts in exocytosis: focus on mast cells. Biochim Biophys Acta 1071:429 471

41. Nili U, de Wit H, Gulyas-Kovacs A et al (2006) Munc18-1 phosphorylation by protein kinase $\mathrm{C}$ potentiates vesicle pool replenishment in bovine chromaffin cells. Neuroscience 143:487500

42. Toullec D, Pianetti P, Coste H et al (1991) The bisindolylmaleimide GF $109203 \mathrm{X}$ is a potent and selective inhibitor of protein kinase C. J Biol Chem 266:15771-15781

43. Park WS, Son YK, Ko EA et al (2005) The protein kinase C inhibitor, bisindolylmaleimide (I), inhibits voltage-dependent $\mathrm{K}^{+}$channels in coronary arterial smooth muscle cells. Life Sci 77:512-527

44. Kim A, Bae YM, Kim J et al (2004) Direct block by bisindolylmaleimide of the voltage-dependent $\mathrm{K}+$ currents of rat mesenteric arterial smooth muscle. Eur J Pharmacol 483:117-126

45. Kraft AS, Anderson WB (1983) Phorbol esters increase the amount of $\mathrm{Ca}^{2+}$, phospholipid-dependent protein kinase associated with plasma membrane. Nature 301:621-623

46. Mellor H, Parker PJ (1998) The extended protein kinase C superfamily. Biochem J 332(Pt 2):281-292

47. Quesada I, Todorova MG, Alonso-Magdalena P et al (2006) Glucose induces opposite intracellular $\mathrm{Ca}^{2+}$ concentration oscillatory patterns in identified alpha- and beta-cells within intact human islets of Langerhans. Diabetes 55:2463-2469

48. Nadal A, Quesada I, Soria B (1999) Homologous and heterologous asynchronicity between identified alpha-, beta- and deltacells within intact islets of Langerhans in the mouse. J Physiol 517 (Pt 1):85-93

49. Ali S, Drucker DJ (2009) Benefits and limitations of reducing glucagon action for the treatment of type 2 diabetes. Am J Physiol Endocrinol Metab 296:E415-E421 